\title{
How Smart is Smart Defense? A Review of NATO's Smart Defense Proposal
}

\author{
Mikaela Blackwood ${ }^{*}$
}

\section{Introduction}

Since 2008, the world has experienced a severe economic crisis, one that has led to many austerity measures, including deep cuts in defense spending in many countries. As NATO Secretary-General Anders Fogh Rasmussen has argued, maintaining a capable and effective NATO Alliance in this era of financial crisis presents a real and pressing challenge for NATO. ${ }^{1}$ In response to these challenges, at the Munich Security Conference in February 2011 Rasmussen launched a proposal for "Smart Defense." This proposal aims to examine how "NATO can help nations to build greater security with fewer resources." It emphasizes the need to "spend better" by prioritizing, specializing, and seeking multinational solutions. ${ }^{2}$

This article will examine and analyze the proposal for Smart Defense with a view to assessing its value in helping NATO surmount the fiscal challenges it faces. The first section will provide a brief overview of the current fiscal environment within NATO member states, including key member states' current and planned defense spending cuts and how these cuts will impact burden sharing within NATO. The next section will briefly describe the Secretary-General's Smart Defense proposal, and will explore each pillar of the concept. The third section will examine the key challenges and strengths of the proposal. Finally, conclusions will be drawn about the ability of the Smart Defense proposal to help NATO overcome the current fiscal challenges.

\section{NATO Burden Sharing and the Fiscal Environment}

Burden sharing within NATO occurs through a variety of direct and indirect contributions to the costs of the Alliance. ${ }^{3}$ The main way member states contribute to the Alliance is through the participation of their national armed forces in NATO, including in operations, and in efforts to ensure that national forces are interoperable with other

\footnotetext{
Mikaela Blackwood works for the Australian Department of Defence. She attended the George C. Marshall Centre in 2011, where she participated in the Program of Advanced Security Studies. The views represented in this paper are solely her own and do not represent the views of the Australian Department of Defence or the Australian Government.

1 Anders Fogh Rasmussen, "NATO and Industry: Providing Security Together," Speech at the ACT Industry Day, London, 12 September 2011.

2 Anders Fogh Rasmussen, "Building Security in an Era of Austerity," Keynote Speech at the Munich Security Conference, 4 February 2011.

3 NATO, "Summary of the meeting of the Economics and Security Committee," 8 October 2011; available from the NATO Parliamentary Assembly website, at http://www.nato-pa.int/ Default.asp?SHORTCUT $=2658$.
} 
NATO members. ${ }^{4}$ At the Prague Summit in 2002, NATO member states made a commitment to spend 2 percent of their GDP on defense in order to ensure that each member state was able to maintain a capable and effective defense force that was interoperable with other NATO forces. ${ }^{5}$

Constrained fiscal environments within member states have a significant impact on NATO, as this may lead member states to reduce their defense budgets and contributions to NATO. Presently, there are two key challenges for NATO stemming from the current fiscal environment: declining defense budgets in many states, which will likely lead to capability shortfalls; and the increasing gap between European and U.S. contributions to NATO resources. Each trend is discussed below and is followed by a review of the likely impacts on NATO.

\section{Declining Defense Budgets}

While declining defense budgets have been a trend for some time now in Europe, the financial crisis in 2008 accelerated this trend. In 2011, for example, eighteen NATO member states spent less on defense than in 2010. ${ }^{6}$ Indeed, in the last two years, Europe's defense spending has gone down by roughly USD 45 billion, which is around the size of Germany's entire annual defense budget. ${ }^{7}$ The United States also faces huge spending cuts with a USD 487 billion reduction to the US Defense budget over the next ten years. ${ }^{8}$ In addition, in 2011 only three of NATO's twenty-eight members met the target of dedicating 2 percent of GDP to defense spending. ${ }^{9}$ As former U.S. Secretary of Defense Robert Gates recognized, the "fiscal, political, and demographic realities make [achieving the 2 percent of GDP target] unlikely to happen anytime soon." 10 Added to this are the concerns that these "cuts have been carried out with little or no coordination with other member states of the Alliance."11

\section{An Increasing Gap between U.S. and European Contributions}

Since the beginning of NATO, there have been concerns about the equality of the Alliance's burden-sharing arrangements, particularly between contributions made by the

4 NATO, "Paying for NATO," 21 November 2011, available at http://www.nato.int/cps/en/ natolive/topics_67655.htm.

5 U.S. Secretary of Defense Robert Gates, "The Security and Defense Agenda (Future of NATO)," Speech delivered at NATO Headquarters in Brussels, 10 June 2011.

6 Frank Boland, "Transatlantic Burden Sharing in a Time of Budgetary Crisis," Presentation to the Annual Meeting of the Economics and Security Committee of the NATO Parliamentary Assembly, Bucharest, 8 October 2011.

7 Rasmussen, "Building Security in an Era of Austerity."

8 U.S. Department of Defense, "Defense Budget Priorities and Choices," January 2012, available at http://www.defense.gov/news/Defense_Budget_Priorities.pdf.

9 Boland, "Transatlantic Burden Sharing."

10 Gates, "The Security and Defense Agenda."

11 NATO, "Summary of the meeting of the Economics and Security Committee." 
United States and those from its European allies. ${ }^{12}$ These concerns have only been exacerbated by the financial crisis, which has led to a widening of the gap between the U.S. and European Allies' contributions. ${ }^{13}$ While ten years ago the United States accounted for just under half of NATO members' total defense spending, it now contributes around 77 percent. $^{14}$

Senior U.S. government officials have warned that the United States may not accept these arrangements forever. In June 2011, former U.S. Secretary of Defense Robert Gates raised important questions about the willingness of the United States to continue to bear so much of the NATO burden: "The blunt reality is that there will be dwindling appetite and patience in the U.S. Congress - and in the American body politic writ large - to expend increasingly precious funds on behalf of nations that are apparently unwilling to devote the necessary resources or make the necessary changes to be serious and capable partners in their own defense." ${ }^{15}$ U.S. Secretary of Defense, Leon Panetta, also raised the prospect that, due to the United States' own budget cuts, it may not be able to bear this burden forever. He said, "As for the United States, many might assume that the United States defense budget is so large it can absorb and cover Alliance shortcomings. But make no mistake about it, we are facing dramatic cuts with real implications for alliance capability." 16

\section{Impact of Fiscal Trends}

The impact of these fiscal trends on the Alliance is twofold: first, they have the potential to affect the capabilities of the Alliance; second, they may have an impact on Alliance cohesion and solidarity. As Pessin argues, these spending cuts "threaten to hurt the NATO alliance's efforts to upgrade its capabilities." ${ }^{17}$ Both Panetta and Gates also spoke of the risks to future investments in modernization, and Secretary-General Rasmussen expressed fears of a "weaker Europe ... without the hardware to back up its soft power." ${ }^{18}$ This has already been seen with a number of delays and cancellations in major equipment projects. Many have also argued that the NATO operation in Libya revealed

12 Karl-Heinz Kamp, "NATO's Chicago Summit: A Thorny Agenda," NATO Defense College Research Paper 70 (Rome, 2011); available at http://www.isn.ethz.ch/isn/Digital-Library/ Publications/Detail/?ots591=cab359a3-9328-19cc-a1d2-8023e646b22c\&lng=en\&id=134581.

13 Anders Fogh Rasmussen, Keynote Speech at the NATO Parliamentary Assembly, Bucharest, 10 October 2011; available at http://www.nato.int/cps/en/SID-67DE56BB-B6463262/natolive/ opinions_79064.htm?selectedLocale=en.

14 Rasmussen, "Building Security in an Era of Austerity"; Boland, "Transatlantic Burden Sharing."

15 Gates, "The Security and Defense Agenda."

16 U.S. Secretary of Defense Leon Panetta, Speech at Carnegie Europe, Brussels, 5 October 2011; available at http://www.defense.gov/transcripts/transcript.aspx?transcriptid=4895.

17 Al Pessin, "Financial Crisis Hits NATO Funding," Voice of America (15 November 2011); available at http://www.voanews.com/content/financial-crisis-hits-nato-funding-133906423/ 148219.html.

18 Rasmussen, "Building Security in an Era of Austerity." 
a number of weaknesses in Europe's military capabilities as a result of their reduced spending on defense. The United States was required to fill in key capability gaps, including targeting specialists; intelligence, surveillance, and reconnaissance capabilities; air-to-air refueling; and supply of munitions. ${ }^{19}$ Second, the increasing gap between the U.S. and its European Allies has the potential to "undermine the solidarity which has long held together this Alliance." ${ }^{20}$ Rasmussen has warned of a "divided Europe" and "a Europe increasingly adrift from the United States." 21

\section{The Smart Defense Proposal}

Many argue that this constrained fiscal environment, coupled with the increasingly complex security environment, makes working together an imperative. It is from this necessity that the concept of Smart Defense was born. Secretary-General Rasmussen first proposed the Smart Defense concept on 24 February 2011 at the Munich Security Conference. He explained, "The way forward lies not in spending more, but in spending better. We must prioritize the capabilities we need the most. Specialize in what we do best. And seek multinational solutions to common problems. This is Smart Defense." 22 Since the initial proposal, Rasmussen has elaborated on the concept a number of times, and in September 2011 he appointed two special envoys-General Stephane Abrial, Supreme Allied Commander, Transformation, and Claudio Bisogniero, then Deputy SecretaryGeneral - to develop a package of multinational projects to be explored at the Chicago Summit in 2012. Each pillar of the Smart Defense proposal is explored below.

\section{Prioritizing}

Secretary-General Rasmussen argues that NATO member states need to "put our money where the real priorities are." At the 2010 NATO Summit in Lisbon, several key priorities for NATO were identified, including operations, cyber security, terrorism, and counter piracy. ${ }^{23}$ As such, Rasmussen has urged member states to spend their precious resources on these priorities, rather than on static defense structures left over from the Cold War. The Secretary-General has encouraged national efforts to reform defense forces to focus on such priorities. For example, he praised the undertakings of the German Bundeswehr, which has embarked upon a reform program to make its armed forces

19 Gates, "The Security and Defense Agenda"; Panetta, Speech at Carnegie Europe; Rasmussen, "NATO and Industry"; and William S. Cohen, Nicholas Burns, and George Robertson, "NATO on the Brink," The Hill (11 July 2011); available at http://thehill.com/opinion/oped/170807-nato-on-the-brink.

20 NATO, "Lawmakers Warn NATO: Defense Cuts Risk Undermining Security," NATO Parliamentary Assembly, Bucharest, 8 October 2011; available at http://www.nato-pa.int/ default.asp?SHORTCUT=2615.

21 Rasmussen, "NATO and Industry."

22 Anders Fogh Rasmussen, "Principles and Power," Speech at the NATO Review Conference, Berlin, 27 October 2011; available at http://www.nato.int/cps/en/natolive/opinions 79949.htm.

23 Rasmussen, "Building Security in an Era of Austerity." 
"leaner, more efficient and more capable." He suggested that Germany can be a "motor for Smart Defense," helping others to undertake similar reforms. ${ }^{24}$ NATO is also undergoing its own transformation process to make the Alliance's command and control function more agile, deployable, and affordable. ${ }^{25}$

\section{Specializing}

Given that the very foundation of the Alliance is about helping one another, SecretaryGeneral Rasmussen has proposed that not all countries need to possess all possible military capabilities (nor, at present, can they all afford them). Instead, specializing in particular capabilities can help reduce the heavy burden of trying to maintain a fullspectrum military force in each nation. Of critical importance to specializing is that each member state does not make these decisions on its own - rather, these decisions must be coordinated and transparent to ensure the Alliance as a whole remains capable and effective. The example of the Baltic States' agreement with NATO on air policing is widely cited as a model. This agreement allowed Estonia, Latvia, and Lithuania to focus their resources on deployable forces in Afghanistan, rather than on expensive aircraft. Another example is the Czech Republic's specialized multinational Chemical, Biological, Radiological, and Nuclear (CBRN) Defense Battalion. It is a NATO facility that all Allies can use, but is led by the Czech Republic. It is designed to "respond and defend" against WMD both inside and outside NATO. ${ }^{26}$

\section{Multinational Solutions}

The final pillar of Smart Defense is multinational solutions, which involve pooling and sharing resources, engaging in common acquisition projects, and promoting common maintenance and logistics efforts. A key example is the effort to build strategic lift capability, where ten NATO allies, plus two partners, pooled their resources to purchase three C-17 transport aircraft. On their own, none of the countries would have been able to afford one $\mathrm{C}-17$, but together they were able to build a strategic airlift capacity that is sufficient for all of the participating states' needs. NATO's missile defense program is also often cited as an example of a multinational solution. By pooling their assets, member states can create an effective missile defense capability to protect their populations. ${ }^{27}$

${ }^{24}$ Rasmussen, Keynote Speech at the NATO Parliamentary Assembly, Bucharest, 10 October 2011.

25 Patrick Wouters, "Technical Background Briefing on NATO Command Structure," interview by Oana Lungescu, NATOChannel.tv (9 June 2011); available at http://www.nato.int/cps/en/ natolive/opinions_75353.htm.

26 NATO Press Release, "Launch of NATO Multinational CBRN Defense Battalion," 1 December 2003; available at http://www.nato.int/docu/pr/2003/p031126e.htm.

27 Anders Fogh Rasmussen, “Towards NATO's Chicago Summit," Speech at the European Policy Centre, Brussels, 30 September 2011; available at http://www.nato.int/cps/en/natolive/ opinions_78600.htm. 


\section{Chicago Summit}

The continuing importance of Smart Defense was reflected in the major focus allies gave it at the Chicago summit in May 2012 where they agreed on a detailed declaration entitled "Summit Declaration on Defense Capabilities: Toward NATO Forces 2020." This declaration highlighted the goal for 2020 of "modern, tightly connected forces, equipped, trained, exercised and commanded so that they to operate together and with partners in any environment." ${ }^{28}$ They noted that progress in Alliance cooperation included: agreement on interim ballistic missile defense capability as an initial step to establish NATO's missile defense system; agreement to deploy a highly sophisticated Alliance Ground Surveillance system; extending the air police mission in the Baltic states; establishment of a new command structure. Steady progress was also achieved in developing other critical capabilities that were identified at the 2010 Lisbon Summit, including: cyber defense; extending NATO's air command and control system; augmenting capabilities in Afghanistan for exchanging intelligence, surveillance and reconnaissance data and countering improvised explosive devices. ${ }^{29}$ At Chicago, allies also adopted a comprehensive Smart Defense package which included more than 20 multinational projects, including for a NATO universal armaments interface for aircraft, remotely controlled robots for clearing roadside bombs, pooling maritime patrol aircraft, multinational cooperation on munitions, a multinational aviation training centre, multinational medical treatment facilities and a multinational logistics partnership for fuel handling among many others. ${ }^{30}$

\section{Summary}

At its core, the Smart Defense proposal is about working together to achieve more than individual states can achieve alone. As the U.S. Permanent Representative to NATO, Ambassador Ivo Daalder, stated, "If you fund things in common, then ten cents can get you a dollar's worth of capability, because the ninety cents get paid for by other allies. If you try to buy that same capability yourself, ten cents gets you ten cents worth of capability, so you're multiplying the effect by going together with other countries." 31

28 NATO, "Summit Declaration on Defence Capabilities: Toward NATO Forces 2020," 21 May 2012, paragraph 5 .

29 NATO, "Summit Declaration on Defense Capabilities: Toward NATO Forces 2020," 21 May 2012, paragraph 4.

30 NATO, "Multinational Projects Fact Sheet," Media Backgrounder, 16 May 2012, available at www.nato.int/nato_static/assets/pdf/pdf_topics/20120516_media_backgrounder_Multinational Projects_en.pdf.

31 Ivo Daalder, "The Success of NATO Operations in Libya and the Vital Contributions of Partners Outside of NATO," Media Roundtable, Washington Foreign Press Center, 7 November 2011; available at http://fpc.state.gov/176760.htm. 


\section{Challenges and Opportunities}

Since the Secretary-General put forward his Smart Defense proposal, there have been a number of questions raised about its likely utility in helping address current fiscal issues. This section analyzes key critiques, and weighs them against the key strengths of the proposal.

\section{Critiques}

The most common critique of the Smart Defense proposal is that it is just another buzzword or bumper sticker slogan. Karl-Heinz Kamp has argued that it is nothing new, that similar buzzwords have been used in the past, and that Rasmussen's proposal is unlikely to achieve anything different this time. As Andrew Michta put it, "buzzwords alone can't provide the fundamentals NATO is missing." 32 Others have furthered these comments by saying that such a concept cannot be a substitute for member states taking responsibility for their fair share of defense. ${ }^{33}$

Of the three pillars, perhaps the most challenging will be multinational solutions. Such solutions often sound good in theory, but in practice it is much harder to achieve tangible results. According to Tomas Valasek, the EU has some experience with pooling and sharing resources. However, due to the sensitivities of individual nations and differences in their strategic outlooks, threat perceptions, and military cultures, these efforts have met with limited success. ${ }^{34}$ He notes that "governments are reluctant to build joint units because this may require them to share decisions on how and when to use them," and that governments fear such activities will "undermine national sovereignty by creating interdependencies with other militaries." ${ }^{35}$ Rasmussen has recognized these barriers: "I know allies don't always find multinational cooperation the most attractive option. There are lingering concerns about delayed delivery schedules, inflated overhead costs, and slow decision making. And of course, defense is tightly bound with national sovereignty, industry and jobs." The complications of joint crewing of assets recently came to bear during Operation Unified Protector, the NATO operation in Libya during the collapse of the Qadhafi regime. Complications arose because NATO Airborne Warning and

32 Kamp, "NATO's Chicago Summit: A Thorny Agenda"; Andrew A. Michta, "NATO's Last Chance," The American Interest (May/June 2011): 56-60; available at http://www.theamerican-interest.com/article-bd.cfm?piece=959.

33 Gates, "The Security and Defense Agenda."

34 Tomas Valasek, "EU Ministers Tackle Defence Austerity," Centre for European Reform blog (1 June 2011), available at http://centreforeuropeanreform.blogspot.com/2011/06/eu-ministerstackle-defence-austerity.html; and Valasek, "Governments Need Incentives to Pool and Share Militaries," Centre for European Reform (1 November 2011), available at http://centreforeuropeanreform.blogspot.com/2011/11/governments-need-incentives-to-pooland.html.

35 Valasek, Surviving Austerity: The Case for a New Approach to EU Military Collaboration (London: Centre for European Reform, April 2011), available at http://www.cer.org.uk/ publications/archive/report/2011/surviving-austerity-case-new-approach-eu-militarycollaboration; and Valasek, "Governments Need Incentives." 
Control System (AWACS) assets - some of which had German crews) - were needed in Libya, but Germany had opted to not be involved in the operation. While the issue was resolved, with the German Parliament approving German-crewed AWACS planes to deploy into Afghanistan in seventy-two hours, which freed up non-German crews for Libya - it does raise concerns about how deployable common assets truly are. ${ }^{36}$

\section{Strengths}

Despite these critiques, the Smart Defense proposal also has a number of strengths and advantages that may overcome the challenges that have been identified. In this era of austerity coupled with complex security challenges, an innovative framework to deal with these problems is needed. The Smart Defense proposal is one such creative solution, and provides a useful conceptual tool to promote further thinking on this critical issue. The concept itself provides a mechanism for identifying opportunities and exploring areas of cooperation. Moreover, the Smart Defense proposal has been formulated in a way that attempts to provide substance beyond just being another buzzword. The appointment of the two high-level Special Envoys and tight timeframes given for delivering a package of proposals (Chicago 2012) demonstrated NATO's institutional commitment to the approach. ${ }^{37}$

Karl-Heinz Kamp has described the current situation as an "almost unique environment with an international financial crisis putting more pressure on national budgets than ever before." 38 He argues that NATO member states may be more willing and more open to explore proposals for meeting their security interests without putting further strain on their national budgets. The concrete package of multinational projects delivered at the Chicago Summit is a clear illustration of member states' commitment to pursue multinational solutions and support the Smart Defense initiative. In addition, Smart Defense's prospects for success are strengthened by NATO's unique position, as it has visibility across the Alliance. It has insights into all member states' current capabilities and capability requirements, and can therefore play a valuable role in coordinating and overseeing these efforts. ${ }^{39}$ In order to overcome the issues of differing perceptions and outlooks, Valasek suggests promoting "“islands of cooperation' along regional lines." 40 Models such as the Baltic States' approach to air policing or the recent France-U.K. Treaty may prove to be useful in the short term as deeper and more extensive cooperation models are developed for the longer term.

\section{Conclusions}

Given the pressure on defense budgets across the NATO Alliance and the increasingly complex security terrain, action is needed to ensure that the economic crisis does not

\footnotetext{
3 Daalder, "The Success of NATO Operations in Libya."

7 Kamp, "NATO's Chicago Summit: A Thorny Agenda."

38 Ibid.

39 Rasmussen, "Building Security in an Era of Austerity."

40 Valasek, Surviving Austerity.
} 
morph into a security crisis as well. The Smart Defense proposal from NATO SecretaryGeneral Anders Fogh Rasmussen provides a valuable conceptual framework for member states to identify further opportunities to prioritize their defense needs, specialize in particular areas of capability, and work multinationally. While challenges and hindrances to working together abound, the unique global environment may provide the necessary impetus to overcome these barriers to cooperation.

Political will is a key ingredient in surmounting these challenges. NATO can use its unique position to encourage member states to work together in these efforts. In sum, if member states are fully committed to making difficult decisions and are serious about working together to develop solutions, it is likely that the concept of Smart Defense will make a significant contribution to helping NATO remain a credible security actor in this era of austerity. 